\title{
Classified Information in The Media Spotlight And Trust in The State
}

\author{
Stanislaw Szabo ${ }^{1}$, Pavol Vitko ${ }^{2}$ \\ ${ }^{I}$ Technical University in Prague, Faculty of Transportation Sciences, Department of Air Transport, Praha, \\ Czech Republic, \\ ${ }^{2}$ Armed Forces Academy General Milan Rastislav Štefánik Liptovský Mikuláš, Department of Security and \\ Defence Studies,Liptovský Mikuláš, Slovak Republic
}

\begin{abstract}
The penetration of media and information technologies into the absolute majority of citizens' lives requires that, in defending and pursuing its intentions in the subject-matter area, the State should view it in the most erudite manner and should be capable of responding to it professionally. This fact is even more crucial in the post-socialist countries, where, in light of their totalitarian past, state bodies are often perceived through the lens of stereotypes as being deformed in the sense that the State performs more repressive than protective roles; that it is a bad owner in general terms; or even that it mismanages the tax payers' money. The situation in the field of security is of special seriousness, where the State, being its principal guarantor, must seek to attain the highest possible level of credibility. However, one of the phenomena that may damage or weaken this credibility is a leak of State-classified information, as a result of which the credibility of an institution responsible for administering the security of classified information could be damaged significantly. As this happens, the persons who may have committed illegal action in the process of information leakage can still be viewed by the public in a positive manner.
\end{abstract}

Keywords: information, data, information system, security risk, communication, crisis communication, leakage of classified information

\section{Introduction}

Information and communication technologies enable concentrating and archiving metadata, including those labelled as classified information pursuant to legislation and internal rules of specific institutions. States and organizations assign increasingly more funding to invest in information security and data protection in information systems. While doing so, legitimacy and credibility is central to their action. With regard to information leaks from information systems, among the most vulnerable spots are human failures and premedited intentions of individuals authorized to access classified information, rather than technical vulnerabilities. In light of their attitudes or conscience, the primary impetus driving their action to release classified secrets to the media may be positive in its nature. In doing so, they may attempt to draw attention to infringements of human rights and fundamental freedoms, breaches of privacy, corrupt behaviour, etc. However, even in such cases, leaks of classified information are still illegal and unlawful, according to legislation. Yet the general public often view an individual's motivation and cause in the media spotlight in a positive, rather than negative, manner, even as a purifying mechanism of democracy. Simultaneously, as a rule, this multiplies the public's mistrust in the State and in its institutions.

In this article we address the issues surrounding the leaks of State-classified information to the media as reflected in the perception and opinions of university students. Our research study on this subject-matter was carried out also with the aim of detecting the underlying tendencies in the attitudes of the target community. For this reason, we repeated the research study in three subsequent years. While doing so, we focused on four key scandals, which greatly reverberated in the Slovak media over the years. Two cases are from Slovakia, one being the Gorilla scandal, i.e. the transcripts of wiretaps leaked from the Slovak Information Agency (hereinafter referred to as "SIS"), with the eavesdropping activity occurring in an undercover flat after 2005 and the wiretap file being leaked to the media in 2012, the other one being the wiretaps of journalists leaked from the SVK Defence Intelligence (hereinafter referred to as "VOS"), when the VOS classified secrets grabbed the media's attention in 2011. Of international scandals, we looked into the effects on university students by the WikiLeaks case, i.e. the leakage of US diplomatic documents in 2010, and the Edward Snowden case, i.e. the leaks of classified information revealing the US administration's global secret surveillance system in 2013.

Although in our thesis we assumed that our target audience sample would perceive the people behind the leaks and the media's spotlighting of State-classified information in a predominantly positive manner, we were more interested to find out the extent of their support of the law violators. Simultaneously, we attempted to ascertain their positions on communications, to be more precise, on the crisis communications that the pertinent 
state bodies conducted in handling the said scandals, with the aim of defining the existing deficiencies in communications and a vision to make improvements in future communications.

\section{Information Leaks Under Research}

The State, as well as other organizations, must increasingly confront the security threats that jeopardize their information systems and networks. In general, a threat carries in itself a potential ability to trigger off an undesirable incident that may cause damage to a system, or to an organization and its activities. Such a threat could arise inside an organization, e.g. an employee-iniciated sabotage, or from outside an organization, e.g. a hacker's malicious attack or industrial espionage.[1] The sources of such damage, including, notably, computer viruses, computer hacking and attacks with denial of services have become increasingly common, more ambitious and complex. A global interconnection of public and private computer networks and sharing of information sources increasingly call for a controlled environment to be developed with clearly determinable guarantees for the provision of information security. [2]

Nonetheless, State-classified information could leak also as a result of personal premeditated failures. At first glance, the phrase "personal premediated failure" may appear to be paradoxical. This may well be explained by the fact that however noble the intentions of key protagonists may have been, whether you consider the WikiLeaks scandal or the Snowden scandal, their actions vis-à-vis the targeted organizations for which the individuals worked were deemed complete failures.

The fact that such information was very quickly and collaboratively taken over by the media (just as it was in the Gorilla scandal and the VOS classified secrets leak scandal) is derived from the nature of the media themselves as well as of the democratic environment in which they operate. It would have been extremely difficult, to be exact, virtually impossible to release such information in a totalitarian regime. One of the main advantages of democracy, with its noble goals and roles, is that it confers freedom upon the media, albeit with legal constraints. On the other hand, the media should be held accountable in a democratic society. This is especially true in a democracy where the State has almost entirely given up its media ownership entitlement and its influence via laws may often be marginal. Unlike in a democracy, the totalitarian state either owns media outlets or has a decisive bearing on them. This leverage may be achieved through their owners, who are either willingly or forcefully loyal to the State, or laws by means of which totalitarian regimes enforce such loyalty. Therefore, releasing classified information in the legal media environment of totalitarian regimes may be almost absolutely ruled out.

In a democratic society, where information has been transformed into a product, one designed as any other commercial product to yield profit, the major driving motive of the mass media, as some of us believe, is not to deliver objective, unbiased and balanced news coverage, but rather to generate economic revenues and achieve economic and political leverage. [3] Additionally, apart from the informative and entertaining value of information, actionability, dramatic suspense, tensions and key messages - these all combine to deliver an impact on the audience.[4] Naturally, dramatic suspense, tensions and unusual classified secrets are closely intertwined. The cummulative effect of these factors may be hugely detrimental and may considerably threaten the credibility of any state-run organization or agency.

In an attempt to verify this thesis, we carried out three opinion surveys. The first one was conducted in 2012, the second one in 2013, and the third one in November and December 2014. As stated before, our research focused on the media's spotlighting of familiar scandals involving leaks of State-classified information. Plus in 2012, we asked the respondents about the leaked video showing the torture and prisoner abuse of Iraqi prisoners at the US-run Abu Ghraib prison in 2006. However, at the time this scandal was already passing into oblivion in the Slovak media. As a result, we omitted it from our research, replacing it with the Snowden scandal, one featuring information leaks disclosing the US administration's global surveillance capabilities system in 2013.

The Gorilla scandal revolved around the leak of recordings of conversations between politicians and financial groups representatives from the years 2005 and 2006 during the second Dzurinda administration. The operational transcripts of the wiretaps point to highly corrupt practices in the Slovak politics and to high levels of leverage on politicians by financial groups. The wiretaps were made in a conspiration flat, where representatives of financial groups, politicians and their staff would meet for discussions. The case is still alive in Slovakia and has not been officially closed. It may be added that it was not until February 2015 that Marek Gajdoš, the chief of the Gorilla investigation team, who has been investigating the case for the past three years, admitted that the wiretap file is, to a certain extent, an authentic document by the SIS. The wiretap file was originally uploaded to an anonymous website and no officials have so far confirmed its authenticity, though the public and analysts are convinced of its legitimacy and perceive it in this perspective. Gajdoš, the chief investigator, made a statement, saying that even though the inquiry into the case has by far not been concluded, a lot of information and facts in the wiretap file have proved to be authentic. 
As part of the Defence Intelligence case, we looked into the wiretaps of journalists which took the media spotlight in November 2011 and resulted in the resignation of the then SVK Minister of Defence, Lubomír Galko. According to the available media information, the director of the TA3 TV Channel and journalists from the Pravda nation-wide newspaper were subject to eavesdropping. Even this inquiry into the case has not been officially closed. The Deputy Prosecutor General for Penal Afffairs, Peter Sufliarsky, announced in February 2015 that there had been partial delays in the progress of police investigators' work, but no unlawful wrongdoings in the investigation process had been detected. As early as 2014, the Deputy Prosecutor General said that the inquiry into the case was taking too much time. It may be noted that the former SVK Prime Minister, Iveta Radičová, who had concurrently assumed the post of SVK Minister of Defence upon Galko's resignation, gave her testimony in February 2015.

All things considered, even though the State-classified information leaks under consideration were unlawful, the public in Slovakia as well as abroad perceived those who were behind the leaks in the media spotlight, to a great extent, in a positive manner. It should be noted that Private First Class Manning was convicted on charges of leaking classified military documents to WikiLeaks in a court ruling. In the case of Edward Snowden, Booz Allen Hamilton, a leading US-based provider of management and technology consulting services, where Snowden was employed, called the leakage as "shocking", adding that it was a "serious breach of the company policy". In response to the US diplomatic correspondance being uploaded at WikiLeaks, the Italian Minister of Foreign Affairs, Franco Frattini, said that it was a diplomatic 9/11. Similarly, reacting to the revelations, the Director of the Czech Institute of International Relations, Petr Drulák, referred to the correspondance as ,political pornography“. The Reuters news agency branded the founder of WikiLeaks as a public enemy No. 1. On the other hand, the petition for granting an amnesty to Edward Snowden, the former US intelligence technician who disclosed the secret surveillance programme monitoring Internet communications to the press, fetched 22,000 electronic signitures in his support in a single day after the petition's launch. Pfc Manning enjoyed a similar massive Internet support. Julian Assange, editor-in-chief of the website WikiLeaks, where Manning released the stolen information, was awarded the Golden Medal by the Sydney Peace Foundation (SPF) on 11 May 2011. Pfc Manning received the award in London for displaying exceptional courage in the fight for human rights. Pfc Manning was the fourth laureate to receive the award in the 14-year-long history of the SPF. In addition, the Norwegian MP Snorre Valen said that thanks to the relevations of corruption, violations of human rights and military crimes, the website WikiLeaks was a natural nominee for the Nobel Peace Prize. As we know the nomination was not upheld in the end.

\section{Classified Information Leaks in The Media Spotlight as Perceived by University Students}

In December 2012, we chose university students of journalistism and mass media communications as our target audience sample. Our choice was based upon the assumption that these students were more interested in political and social developments at home and abroad. Moreover, after graduating from their studies, they would, in their future jobs, participate in shaping the public opinion. With this in mind, in December 2012, we delivered a total of 120 questionnaires to students at two universities and one academy based in Bratislava as distribution and collection points, i.e. the Department of Journalism, Faculty of Philosophy, Comenius University (a state-funded tertiary education establishment with $63 \%$ of respondents), and the Faculty of Mass Media, the Pan-European University and the Media Academy - School of Media and Marketing Communications (both privately funded tertiary education establishments with $37 \%$ of respondents). A total of 93 questionnaires were returned to us, which accounts for a 75-percent returnability rate.

In November and December 2013, for our target audience sample we chose not only university students of journalism from Bratislava but also students of international relations and political sciences from Banská Bystrica, which is a similar study programme. Of the 150 questionnaires, 120 were returned to us, which accounts for an 80-percent returnability rate. Among the respondents were students from the Department of Journalism, Faculty of Philosophy, Comenius University (22\% of respondents), Faculty of Mass Media, PanEuropean University (21\% of respondents), Media Academy - School of Media and Marketing Communications (24\% of respondents) and Matej Bel University in Banská Bystrica (33\% of respondents).

In November and December 2014, we decided to distribute 140 questionnaires. A total of 126 questionnaires were returned to us, which accounts for approx. a 90-percent returnability rate. Among the distribution and collection points were the Department of Journalism, Faculty of Philosophy, Comenius University (40\% of respondents), Faculty of Mass Media, Pan-European University (38\% of respondents), and Media Academy - School of Media and Marketing Communications (22\% of respondents).

The responses to closed questions were compared using the quantitative method, having the advantage of providing objective results independenly of the researcher, i.e. (more or less statistical) data that can be used clearly and unambiguously in presentation tables and charts. 
Figure 1 Which of the scandals involving leaks of classified information did you perceive most intensely (December 2012)?

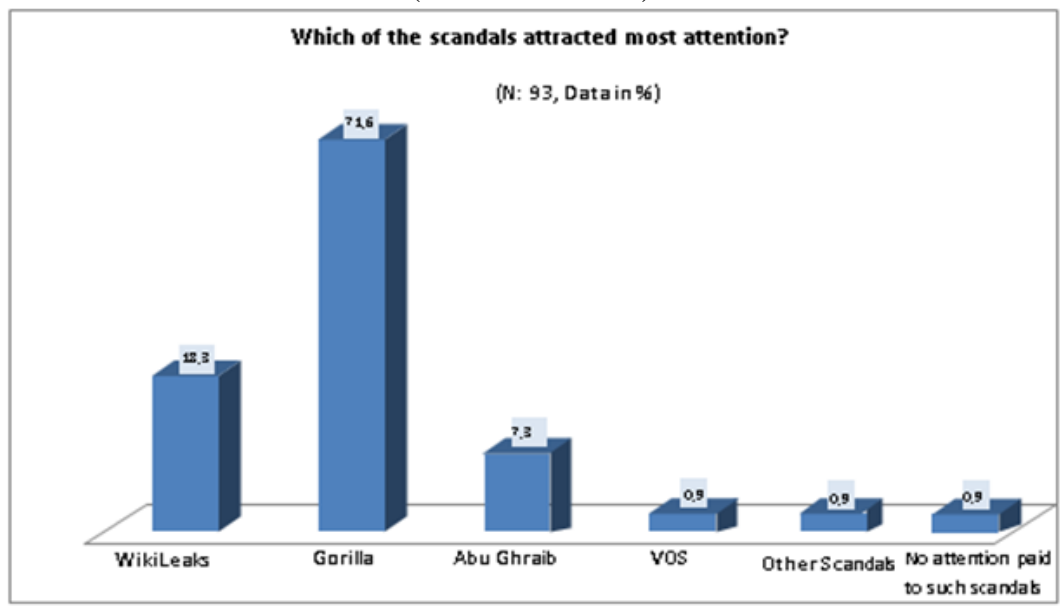

Figure 2 Which of the scandals involving leaks of classified information did you perceive most intensely (December 2013)?

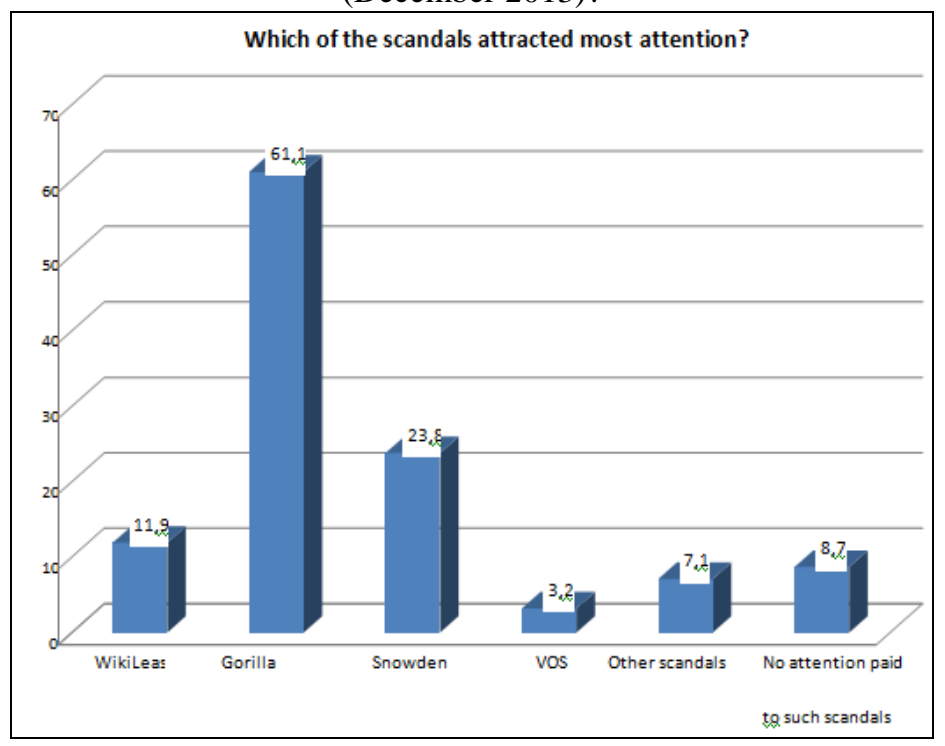

Figure 3Which of the scandals involving leaks of State-classified information did you perceive most intensely (December 2014)?

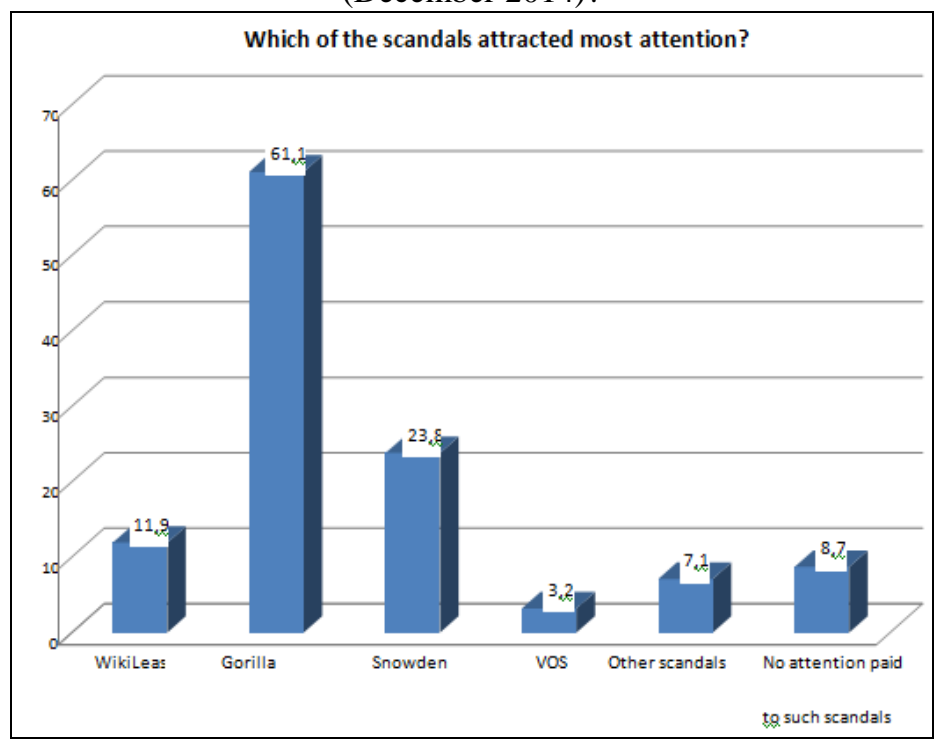


Our research has demonstrated that over the 3-year period, of the listed scandals, university students have most intensely perceived the Gorilla scandal, i.e. the leak of wiretap transcripts indicating highly corrupt practices in the Slovak politics and high levels of leverage on politicians by financial groups: $(71.6 \%, 38.2 \%$ and $61.1 \%$ ). It was not until 2013 that the Snowden scandal edged closer towards the Gorilla viewing rates with $33.8 \%$, otherwise the differences in viewing rates were in dozens of percentage. Bearing in mind that the target audience sample was primarily made up of university students of journalism, we did expect a much higher level of interest in the Defence Intelligence case, as it involved eavesdropping on journalists $(0.9 \%, 7.6 \%$ and 3.2 $\%)$.

The leakage of the U.S. classified diplomatic correspondance, i.e. the WikiLeaks case (Private First Class Manning and Julian Assange), sustained, more or less, its viewing rates (18.3\%, $15.5 \%$ and $11.9 \%)$, with a tendency to gradually fall. Despite the fact that the Snowden scandal is still alive, the interest in it has dropped from $33.8 \%$ to $23.8 \%$.

Figure 4.How do you view the journalists, civil servants, service personnel and others involved in leaking and releasing classified information (December 2012)?

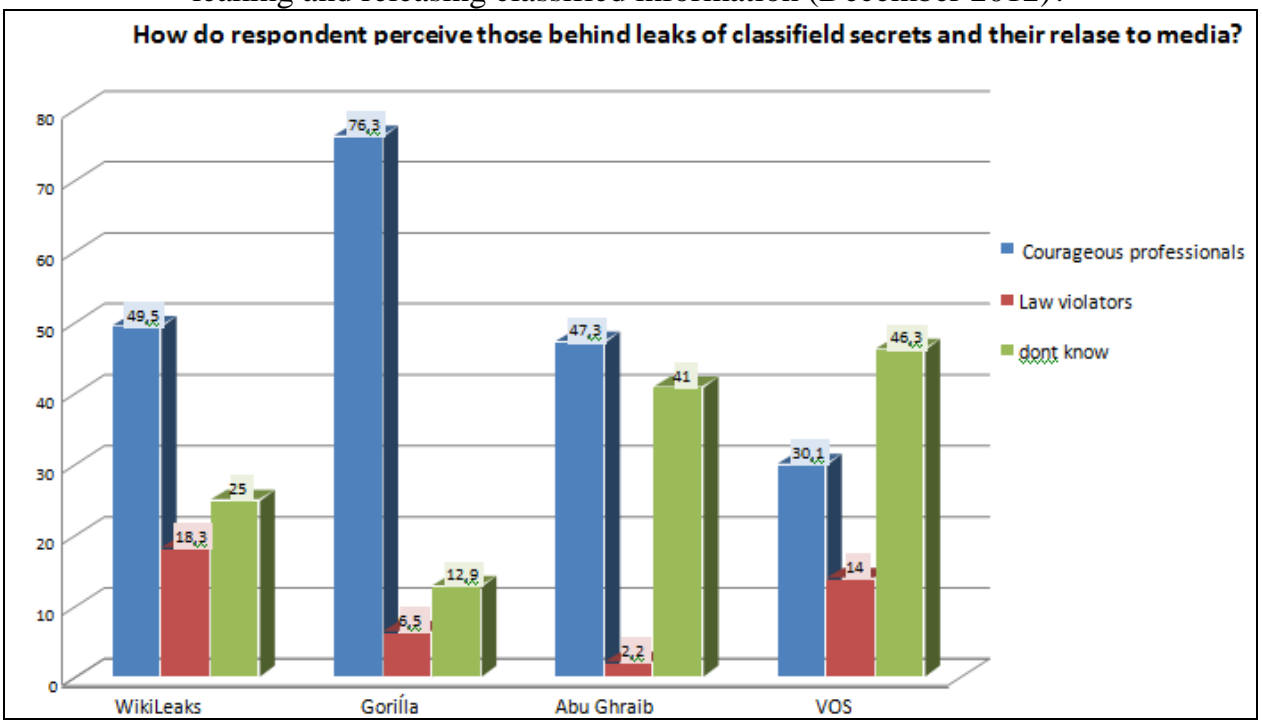

Figure 5. How do you view the journalists, civil servants, service personnel and others involved in leaking and releasing classified information (December 2013)?

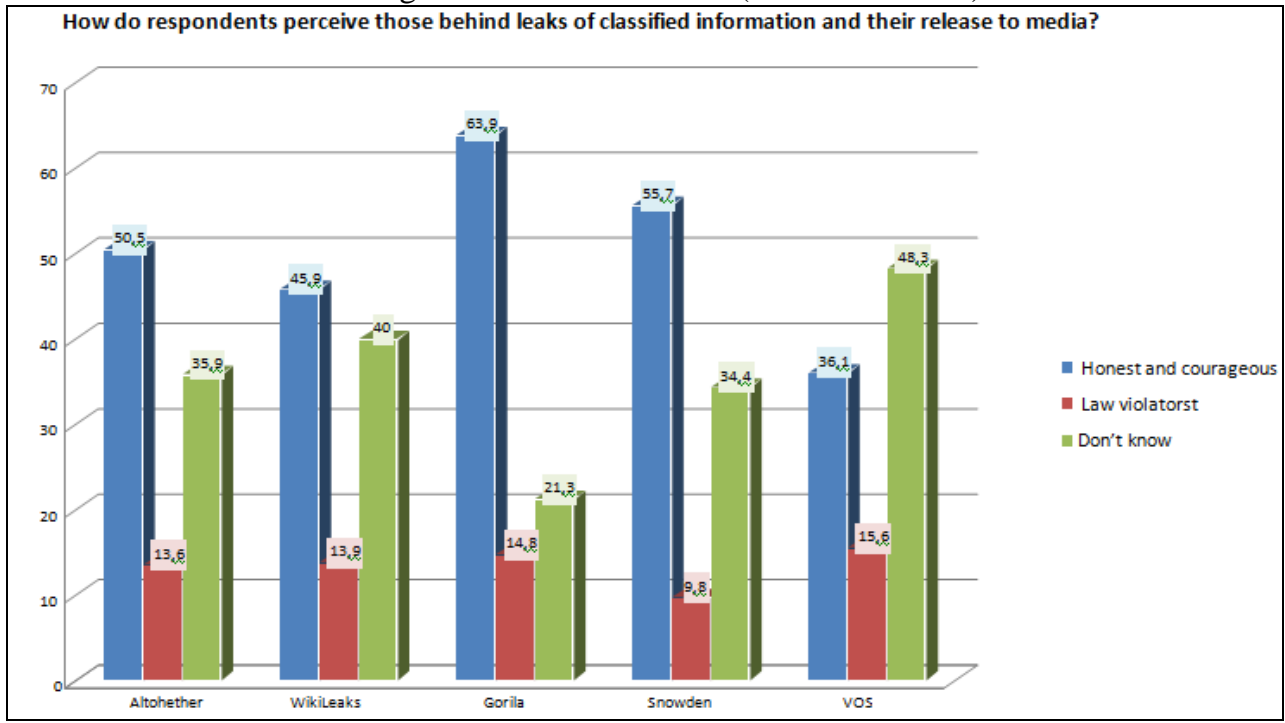

How do the public view those involved in leaking and releasing classified secrets to media? In our thesis we assumed, despite the illegal nature of information leaks, that the student audience considered the people behind the leaks and their release to media as more of positive figures, i.e. people who, from their perspective, acted correctly in an attempt to reveal the truth and thus tried to remidy the existing flawed rules and procedures. This thesis proved to be right. It was best demonstrated in the Gorilla scandal (76.3\%, $63.9 \%$ 
and $64.3 \%$ ). On the other hand, the least preferences were given to those who were invovled in releasing the classified secrets of the Defence Intelligence (30\%, $36 \%$ and $24 \%$ ). At the same time, a large number of respondents were not able to evaluate the leakage of classified secrets from the VOS $-46.3 \%, 48.3 \%$ and $63.5 \%$, which was considerably surpassed the figures we had expected.

Figure 6. How do respondents perceive those behind leaks of classified information and their release to media? (December 2013)?

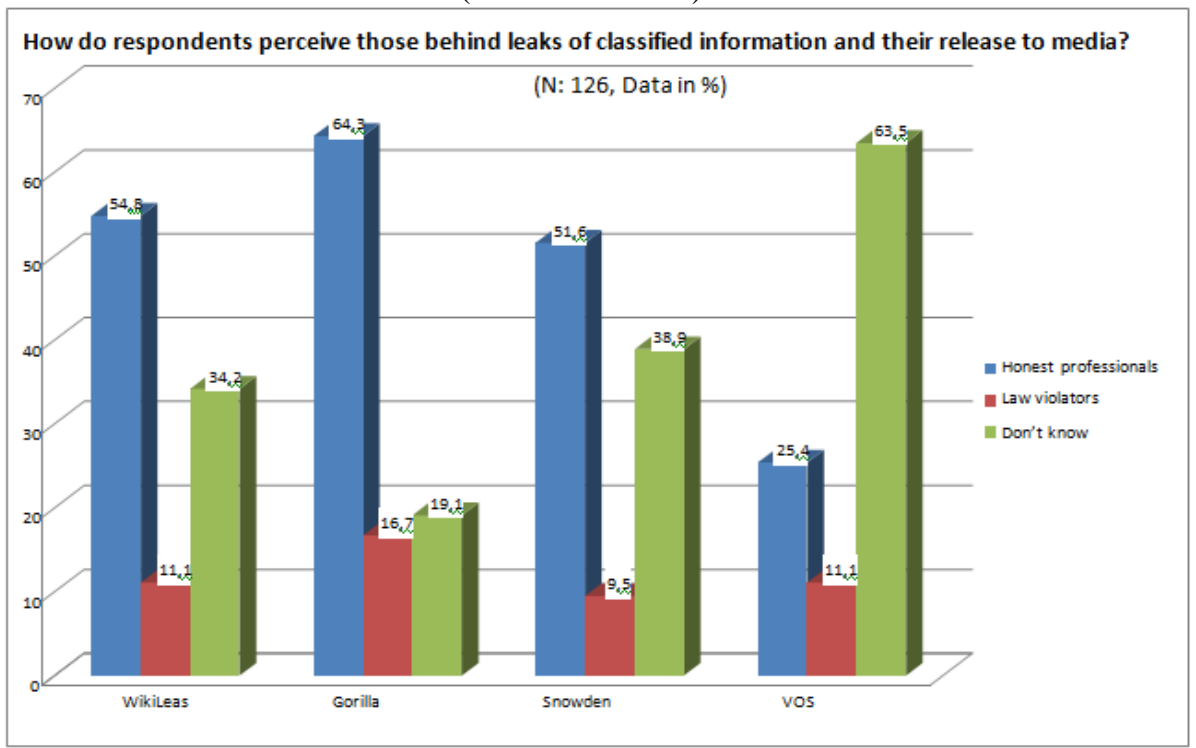

Figure 7. How professionally did the pertinent state bodies handle the said scandals (2014)?

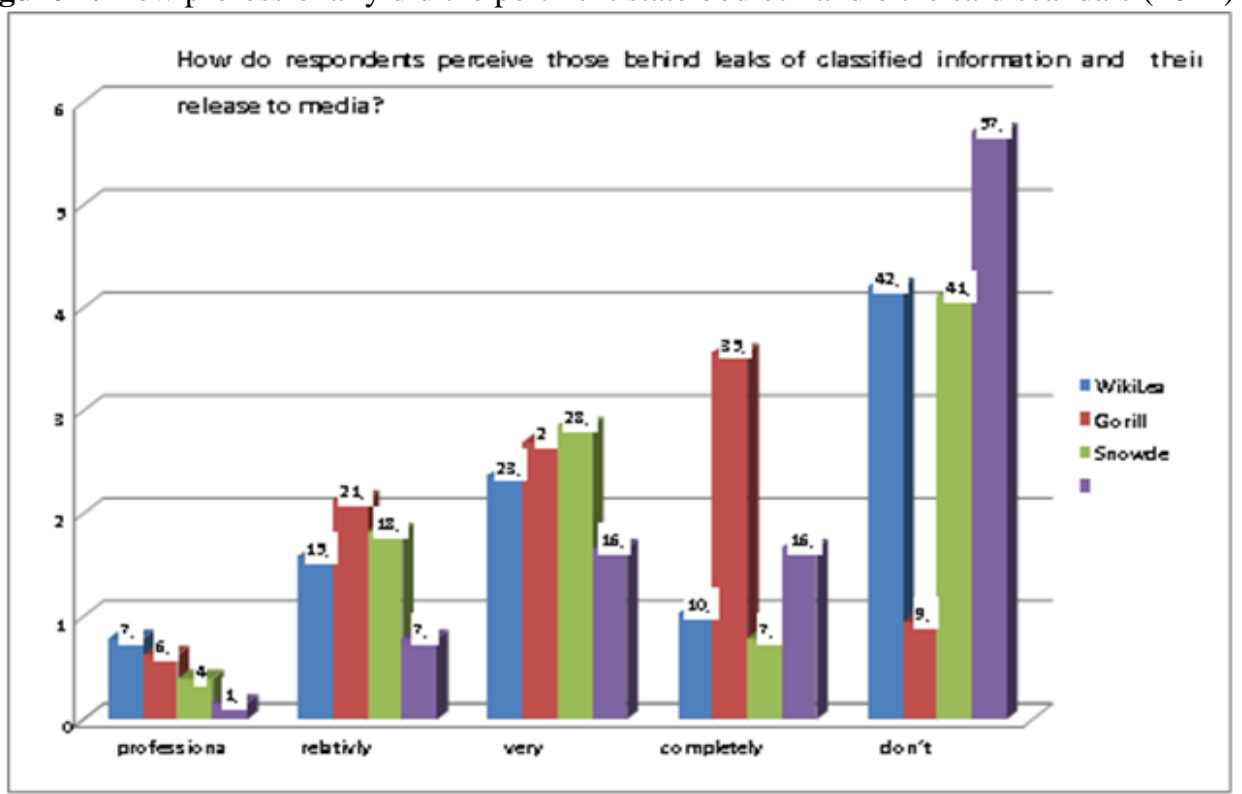

At the same time, we were interested to know how the students of journalism and mass media communications perceived communications, to be more precise, the crisis communications by the pertinent state bodies in handling and providing explanations and clarifications for the classified secrects leaked to media. As the results in the first two years were similar (and due to limited space), we have released a chart integrating the other research issues in the 2014 opinion survey. In it, the results demonstrate that the professionality of communications as handled by the State was viewed negatively rather than positively. In this respect, the worst rating, i.e. $62.7 \%$, received the Gorilla scandal in 2014. The said scandal was communicated very poorly to the public even in $2012(64.5 \%)$ and in $2013(62 \%)$. Again, we were greatly surprised to find out that in December 2014 a total of $57 \%$ of respondents were unable to express their opinion on the VOS case, compared to $59.2 \%$ in 2012 . 
In addition, we looked into what the respondents most opposed in the way the state bodies handled crisis communications. However, it is not the aim of this article to go into detail. Nevertheless, it should be noted that, in general, the respondents opposed any kind of disinformation. With regard to media communications, the Gorilla scandal received the most negative rating, with $39.8 \%$ in 2012, $47 \%$ in 2013 and $45.2 \%$ in 2014.

Figure 8. What may the media's spotlighting of classified information mean for society (2014)?

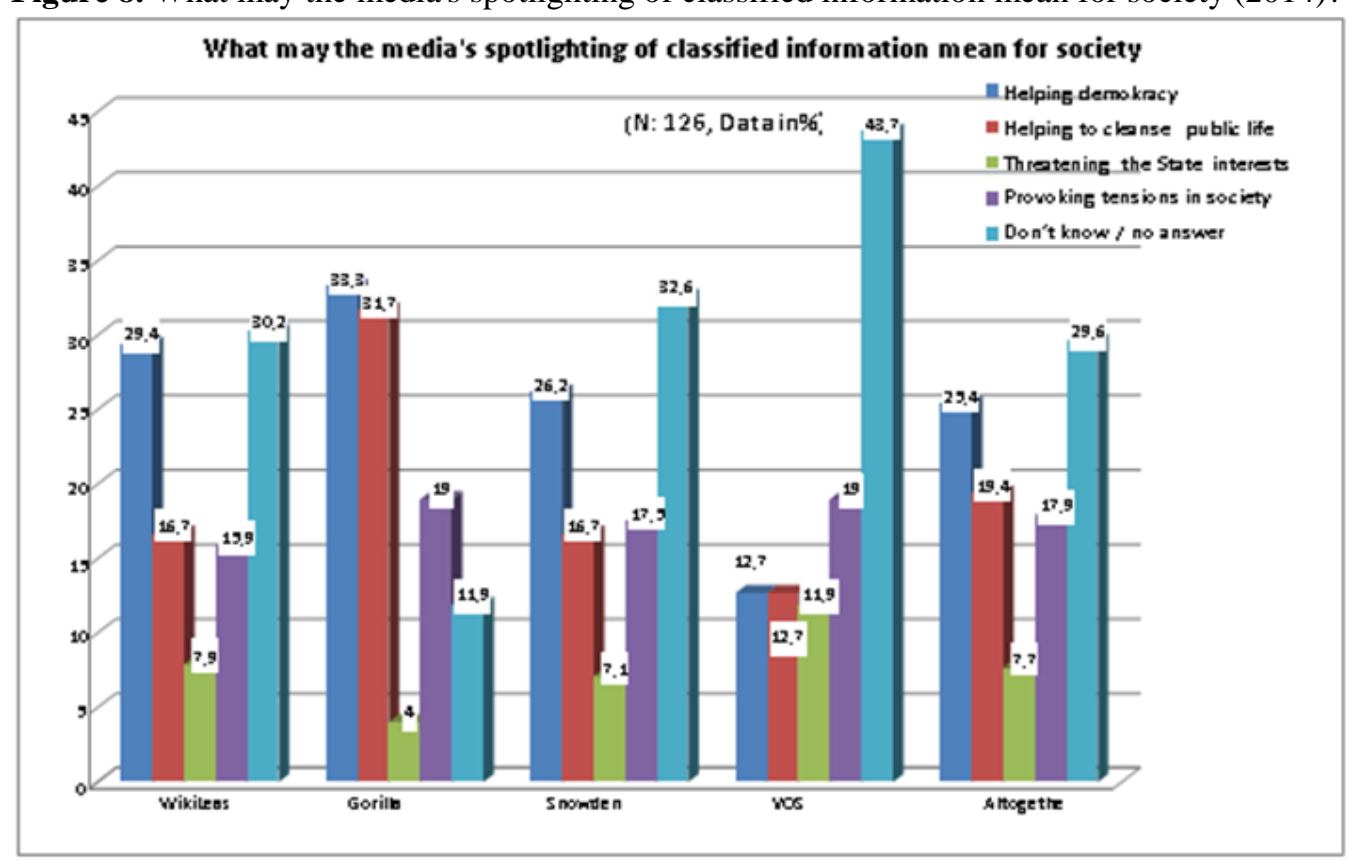

We asked the respondents to express their opinion on what the media's spotlighting of State-classified secrets may mean for society. While analyzing the answers, it may be concluded that, in considering this issue, the respondents demonstrated a positive mindset. Although it was clear to them that the said leaks were illegal, according to them, this may help improve democracy and cleanse the public life (altogether for all scandals 73.2 $\%$ in 2012, 67.2 \% in 2013 and $41.8 \%$ in 2014). Also, some respondents were aware of the fact that such leaks may threaten the State's interests or provoke tensions in society. They were inclined towards this viewpoint, as best illustrated by the reactions to the VOS classified secrets leak in the three subsequent years, with $26.9 \%$ in 2012 (just as WikiLeaks), $35.3 \%$ in 2013, and $30.9 \%$ in 2014.

\section{Conclusion}

The conflict between the media and the State power has been a topical issue for over the past century. However, it is now assuming unprecedented dimensions. This is because the State power is no longer commensurate with the political power only (its privileges have been multiplied by the rise of political and economic powers). At the same time, the press and the media are no longer automatically dependent on the political power only. One can say that the State power consists more in communications, rather than in action. [5] If the State is to preserve its status of a relevant and influencial parnter in communications, it must not lose its credibility. One of the things that does threaten this credibility is the media's spotlighting of leaked Stateclassified secrets.

To research this theme, we conducted three successive opinion surveys, with university students of journalism and mass media communications as our target audience sample. This was especially because in this target group we had expected to see a greater and deeper interest in local and global developments, as these forms the core of their studies. Moreover, they are the very people who will play a role in shaping the public opinion. Despite the illegal nature of classified secrets leaks, the selected student audience considered those involved in the leaks more of positive figures, i.e. people who, in their perception, acted correctly in an attempt to reveal the truth and thus tried to remidy the existing flawed rules and procedures.

Our thesis has proved to be right. It has been evidenced by the results of our research, based on three opinion surveys carried out in three successive years, i.e. in the December of 2012, 2013 and 2014, respectively. In them, we monitored the attitudes of respondents towards the leaked classified secrets in the world's most famous, WikiLeaks and Edward Snowden, scandals, as well as in Slovak scandals, one being the Gorilla scandal, i.e. the leaked transcripts of wiretaps by the Slovak Information Agency (SIS), which point to the 
leverage on politicians by financial groups, the other one being the leaked wiretaps of journalists by the SVK Defence Intelligence (VOS).

Reflected in the students' opinions, those who caused the leaks of classified secrets in the abovementioned cases were viewed a lot more positively than negatively. In this respect, the most positive attitudes towards the law violator(s) were recorded in connection with the Gorilla scandal, with an approval rate of 76.3 \% in December 2012, $63.9 \%$ in December 2013 and 64.3\% in December 2014, while the least preferences were given to those behind the classified secrets leaked from the SVK Defence Intelligence, recording an approval rate of $30 \%, 36 \%$ and $24 \%$ in 2012, 2013, 2014, respectively.

Between one third and one half of respondents believe that, in terms of media commmunications, the pertinent state bodies handled the scandals either "very poorly" or "completely insufficiently". In December 2014, this opinion was shared by $36.5 \%$ in the Snowden case, while $22.3 \%$ believed it was "professional" or "relatively good". However, over $40 \%$ abstained from answering this question. In the case of the Gorilla scandal the ratio was $62.7 \%: 27.7 \%: 9.5 \%$. The research results in the two previous years, 2012 and 2013 , were similar.

Another important answer was the consideration of what the media's spotlighting of classified secrets may bring to society? In the answers to this question, we recorded a shift in opinions over the years. While in December 2012, $73.2 \%$ believed that the Gorilla scandal would be instrumental to improving democracy and cleansing the public life and $15 \%$ reported that this could threaten the State's interests or provoke tensions in society, in December 2014, these figures shifted down to $65 \%$ for the former statement and up to $23.8 \%$ for the latter statement.

However, what surprised us about this question was the reaction of respondents to the classified secrets leaked from the SVK Defence Intelligence (VOS). While in 2012, $20.5 \%$ believed that a classified information leak may be instrumental to improving democracy and cleansing the public life and $26.9 \%$ said it may threaten the State's interests or provoke tensions in society, in 2014 , the ratio was $25.4 \%$ to $30.8 \%$. Admittedly, a considerable number of respondents were unable to answer this question. Generally speaking, this may signal that university students recognize the importance and responsibility of the State in protecting classified information.

At present, each State and state entity must be capable of asserting its own rights still alone while taking account of the worst development scenarios. Admittedly, there is no government in the world which would possess absolutely reliable tools to do so - including the provision of classified information security. [6] Therefore, just as it is important to technically protect information systems and their contents, it is equally necessary to provide guidance for and educate civil servants to cultivate loyalty and allegiance. On the one hand, in a democracy, the leverage of the media on the State's policy is usually greater than vice versa. On the other hand, mass media constitute a signifcant pillar of democracy, one that has the potential to control politicians and force them to take responsibility for their actions in the public, which is, of course, a positive element.

From the viewpoint of the State's interests and the requirement to provide the public with objective information coverage, a problem is surficing whereby the less and less regulated media (resulting from the media's problematic internal codes of ethics as well as from the media's increasing external liberal regulation due to legislation) are, in pursuing their own interests and the economic and political interests of their owners, increasingly aggressive, unbalanced and unobjective. All in all, mass media communications are capable of outraging, provoking, spurring as much as placating and de-accelerating others in their determination. Moreover, they are capable of persuading others about the truth, as much as they are capable of spreading lies in a trustworthy manner. [7]

In conclusion, it is of greatest importance for the pertinent state bodies to work in compliance with legislation and generally binding rules of ethics. Because if the State fails to do so and keeps breaching its own laws, some individuals responsible for the security of classified secrets may abandone loyalty and abidance by law. What then prevails is a loyatly to generally binding rules of ethics, and such individuals finally resort to releasing their vision of the truth - leaking classified secrets.

\section{References}

[1] BAJČAN, R.: Techniky Public Relations aneb Jak pracovat s médii. Praha: Managment Press, 2003. 148 pp., ISBN 80-7261-096-1

[2] HRADISKÁ, E., BREČKA, S., VYBÍRAL, Z.: Psychológia médií. Bratislava: Bratislavská vysoká škola práva, 2009. 418 pp., ISBN 978-80-89447-12-1

[3] NEČAS, P., IVANČÍK, R.: Globalizácia obrana a bezpečnost'. Liptovský Mikuláš: Akadémia ozbrojených síl generála M. R, Štefánika, 2011. 192 pp., ISBN 978-80-8040-425-3

[4] RAMONET, I.: Tyrania médií. Praha: Mladá fronta, 2003. 232 pp., ISBN 80-204-1037-6

[5] SAMSON, I.: Medzinárodný terorizmus, Implikácie pre Slovensko, Bratislava: Výskumné centrum Slovenskej spoločnosti pre zahraničnú politiku, 2003. 252 pp., ISBN 80-9681-3-4

[6] SULliVANOVÁ, M.: Tlačový odbor $\mathrm{v}$ demokracii. Viedeň: Úrad pre medzinárodné informačné programy Ministerstva zahraničných vecí USA - regionálna kancelária Viedeň, 2003. 72 pp., RPO 2003-113

[7] ŠMIHULA, D.: Použitie silových prostriedkov v medzinárodných vzt’ahoch., Bratislava: Veda, 2007. 282 pp. ISBN 978-80-2240975-9 
[8] TRAMPOTA, T., VOJTĚCHOVSKÁ, M.: Metody výzkumu médií. Praha: Portál, 2010. 294 pp., ISBN 978-80-7367-683-4

[9] RZEPKA, A., Communication Processes as a Tool of Cooperation and Regional Development, China - USA Business Review, Vol.15, Nr 2, February 2016 (Serial Number 152), pp.69-89, doi: 10.17265/1537-1514/2016.02.003

[10] VYBÍRAL, Z.: Psychologie komunikace, Portál, Praha 2009, 320 pp., ISBN 978-80-7367-387-1

[11] Erić, D., Bačík, R., Fedorko, I.: Rating decision analysis based on iOS app store data, Quality Innovation Prosperity, 18 (2), $27-37$ pp.,

[12] OLAK, A.: Człowiek jako podmiot systemu bezpieczenśtwa, Košická bezpečnostná revue, VŠBM Košice, 1/2013, 91-98 pp.. ISSN $1338-4880$

[13] OLAK, A., KOZACZUK, F., KRAUZ, A.: Edukacja dla bezpieczeństwa. Stowarzyszenie, Edukacja. Nauka. Rozwój“, Ostrowiec Św.2011.

[14] KAMENICKÝ, J., Čermáková, H., Soušek, R., Němec, V.: Multiple Measurement of Physical Quantity from the Risk Evaluation Point of View, The 15th World Multi - Conference on Systemics, Cybernetics and Informatics; July 19.-22.2011, Orlando, Florida USA; International Institute of Informatics and Systemics; (volume I.) s. 212 - 215 pp., ISBN 13 978-1-936338-28-3 (Collection), ISBN 13 978-1-936338-29.

[15] SOWA B., Otoczenie i jego relacje z organizacja [w:] Zarzadzanie $w$ zarysie, pod red. Kazimierza Jaremczuka, Podręczniki Uczelniane Nr 109, Wyższa Szkoła Prawa i Administracji w Przemyślu, Przemyśl -Rzeszów 2011, s. 28-32, ISBN 9788363179069, 978-83-63179-06-9. 